\title{
Development of a technology for the production of a functional food based on plant raw materials
}

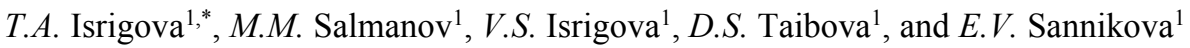 \\ ${ }^{1}$ Dagestan State Agrarian University, Makhachkala, Russia
}

\begin{abstract}
The purpose of the work is to develop a technology for the production of a functional beverage. Methodology of the work. The experiments have been carried out using modern generally accepted techniques. Results of the work. For the first time, technologies and recipes of drinks based on mulberries and other fruit and berry raw materials have been developed using a new method of water purification. The field of application of the results is the food industry. Recipes of functional drinks from natural raw materials have been developed, without the use of dyes and color and taste improvers. A technology for the production of drinks with a new method of water preparation has been developed, and a tasting assessment of drinks have been carried out.
\end{abstract}

\section{Introduction}

Today, human health is the most important priority of the state. Food products must not only meet the physiological needs of a person for nutrients and energy, but also perform preventive and therapeutic tasks. These are the main principles of the state policy of the Russian Federation in the field of healthy nutrition of the population for the period up to 2020 (decree of the government of the Russian Federation No. 1134-R of June 30, 2012) and Supplement of 29.06.16. "Strategy for improving the quality of food products in the Russian Federation up to 2030" (decree of the government of the Russian Federation No. 1364-R of 29.062016 ).

Insufficient amounts of micro - and macronutrients lead to the spread of diseases such as diabetes, diseases of the cardiovascular system and, in general, to a decrease in the body's defenses.

According to the Decree of the Chief State Sanitary Doctor of the Russian Federation, "more than $50 \%$ of subjects are iodine deficient, $60-80 \%$ of the examined people suffer from vitamin C deficiency, 40-80\% have deficiency of vitamins B1, B2, B6, and folic acid, and more than $40 \%$ of the population has a lack of carotene. About $99 \%$ of the population is deficient in protein to some extent."

In Russia, soda water, juices, nectars, fruit drinks, mineral waters, kvass are in demand by more than 130 million people, or $90 \%$ of the population. New types of beverages that have medicinal and functional properties include the use of high-quality water. Water is the

* Corresponding author: isrigova@mail.ru 
most essential component of the human diet. According to medical data, an adult should consume 2.5 liters of liquid per day. A person can have a thirst when the water content in the body decreases by only 1-1.5 liters.

The development of the food additives' market has led to the fact that most manufacturers have industrialized the production of food using synthetic dyes, flavorings, essences, concentrates, which adversely affect the human body as a whole. The development of new recipes and bases for soft drinks, balanced and physiologically complete, from natural, high-quality, safe and environmentally friendly raw materials is very relevant at the present time [16-20].

The relevance of scientific research is determined by its implementation in accordance with the implementation of the state program "Strategy for healthy nutrition, improving the quality of food products in the Russian Federation up to 2030".

The aim of our research is to develop a technology for the production of functional fruit and berry drinks from natural raw materials based on purified water.

These studies have been carried out at the Department of commodity science, food technology and catering of the Dagestan State Agrarian University, where scientists have been developing technologies for the production of functional products [1-10] for 20 years.

\section{Materials and methods}

All studies were carried out at the Dagestan State Agrarian University, at the Department of Commodity Science, Food Technology and Catering, according to generally accepted modern methods.

The main research results were obtained at the Department of Commodity Science, Food Technology and Catering of the Dagestan State Agrarian University named after M.M. Dzhambulatov. The developed technology of drinks based on natural ecologically friendly raw materials was tested at the enterprise "Makhachkalinskiy Vinzavod". As a result, exaples of soft drinks were obtained.

The objects of our research were fruit and berry raw materials, such as sea buckthorn, wild rose, feijoa, mulberry, grapes; extracts from fruits and berries; mulberry concentrate; drinking water from different regions of our republic; samples of prepared soft drinks, drinking water.

Methods for purifying the drinking water were developed at a water treatment unit, which is located in the village of Bogatyrevka (Kirovsky district of Makhachkala) [12].

The quality of raw materials, water and drinks were tested in the Accredited Testing Laboratory of the Dagestan State Agrarian University, and in the laboratory of physical and chemical tests of the Institute of Geology of the Dagestan Scientific Center of the Russian Academy of Sciences.

During the research, the following reference documentation was used: GOST 15101-98 "Procedure for the implementation of research"; "Methodological instructions for chemical and technological testing of vegetable, fruit and berry crops varieties", 1993.

Scientists of the Dagestan State Agrarian University provide the research on the production of healthy food, there is a scientific school for the development of technology for the production of functional food, the main food products are listed in the bibliography [1-10].

\section{Results and discussion}

The technological scheme for the production of functional fruit and berry drinks based on purified water includes the following stages (figure 1): 
- Preparation of water

- Preparation of components for beverages

- Preparation of sugar or stevia syrup

- Preparation of blended syrup

- Preparing a ready-made drink

- Filling, capping, labeling

- Storage of ready-made beverages.

The results of studies of water after purification using our technology for compliance with the requirements of TU 013100-012-00493600-2015 "Drinking water for the production of beverages" are presented in table 1 .

Table 1. Results of studies of water after treatment for compliance with the requirements of TU 013100-012-00493600-2015.

\begin{tabular}{|c|c|c|}
\hline Name of indicators & $\begin{array}{c}\text { Permissible } \\
\text { concentration }\end{array}$ & $\begin{array}{c}\text { Content } \\
\text { after purification }\end{array}$ \\
\hline Smell at $20^{\circ} \mathrm{C}$, points & 0 & 0 \\
\hline when heated to $60^{\circ} \mathrm{C}$ & 1 & 0 \\
\hline Aftertaste, points & 0 & 0 \\
\hline Turbidity, FTU & 1.0 & 0 \\
\hline Color, degrees & 5 & 2 \\
\hline $\mathrm{pH}$ & $6.5-8.5$ & 8.0 \\
\hline Total Dissolved Solids, mg/l & 1000.0 & 978 \\
\hline Bicarbonates, mg/l & 400 & 122 \\
\hline Fluorides, mg/l & 1.5 & Less than 0.01 \\
\hline Sulphates, mg/l & 250 & 0.2 \\
\hline Chlorides, mg/l & 250 & 195.5 \\
\hline Magnesium, mg/l & 65 & 39.6 \\
\hline Sodium, mg/l & 200 & 108.5 \\
\hline Calcium, mg/l & 130 & 126.8 \\
\hline Iron, mg/l & 0.3 & Less than 0.1 \\
\hline Hardness, meq/L & 7.0 & 2.05 \\
\hline Nitrates, mg/l & 20 & Less than 0.1 \\
\hline Cadmium, mg/l & 0.001 & Less than 0.0001 \\
\hline Zinc, mg/l & 5.0 & 0.070 \\
\hline Arsenic, mg/l & 0.01 & Less than 0.005 \\
\hline Lead, mg/1 & 0.01 & 0.0014 \\
\hline Copper, mg/l & 1.0 & 0.001 \\
\hline Mercury, mg/l & 0.0005 & Less than 0.00001 \\
\hline
\end{tabular}

As a result of water treatment using the new technology, all indicators meet the requirements of TU 013100-012-00493600-2015.

Studies show that this method of water purification can be used in regions with a high content of arsenic and other impurities in the water, both for the supply of drinking water to the population, and for food enterprises that purify water for the production of beverages and bottled water.

For the production of soft drinks we used extracts of feijoa, sea buckthorn, dried apricots, rose hips, direct-pressed juices from white Rkatsitelli and black Isabella grape varieties, and mulberry concentrate.

Sugar syrup was prepared by hot method. The calculated amount of water should be poured into a syrup-making boiler and heated to a boil, then with constant stirring the calculated mass of sugar is loaded into the boiler. After complete dissolution of the sugar, the solution is heated to a temperature not lower than $85^{\circ} \mathrm{C}$ and with constant stirring age for at least 30 minutes to completely destroy the mucus-forming bacteria. Boiling is 
stopped when the mass fraction of dry substances in the syrup reaches $60-65 \%$. Then the hot syrup is filtered from coarse mechanical impurities through trap filters $(1-2 \mathrm{~mm})$, after which the syrup is cooled in a heat exchanger to a temperature of $+20-25^{\circ} \mathrm{C}$ and is transferred by a pump to a blending container. In the finished sugar syrup, the volume, mass fraction of dry substances, color, turbidity, ash content and organoleptic parameters are checked, and we also check the syrup for the presence of mucus-forming bacteria, which presence is not allowed. The tank for making sugar syrup should be rinsed with treated water and its pipelines, filter, heat exchanger and pump are washed. Wash water flow to the settler or blending tank.

To prepare sugar syrup of a given mass fraction of dry substances, the required amount of sugar and water per cooking should be calculated.

Example: we have to prepare 1000,0 dm 3 of sugar syrup with a mass fraction of dry substances of $65 \%$. We find the density of $65 \%$ sugar solution, it makes $1.3163 \mathrm{~kg} / \mathrm{dm} 3$.

The mass of $1000,0 \mathrm{dm} 3$ of syrup is: $1000 \times 1,3163=1316,3 \mathrm{~kg}$;

the amount of sugar in this syrup: $1316.3 \times 65,100=855.595 \mathrm{~kg}$;

the amount of water in this case will be: $1316.3 \times 35,100=460.705 \mathrm{~kg}$;

When cooking sugar syrup, water is evaporated depending on the duration of boiling by $2-5 \%$. Therefore, the required water consumption for sugar dissolution, taking into account its evaporation (for the calculation we take $5 \%$ ), will be:

$460.705 \times 1.05=483.740 \mathrm{~kg}$

The actual consumption of sugar increases in accordance with its humidity. The mass fraction of moisture in sugar sand is $0.15 \%$, therefore, the required amount of commercial sugar will be:

$855.595+(855.595 \times 0.15,100)=856.878 \mathrm{~kg}$.

Stevia was used in the form of tablets weighing $0.1 \mathrm{~g}$. To prepare stevia syrup, tablets were previously dissolved in water.

The amount of stevia in the drink was calculated by taste. Two tablets weighing $0.1 \mathrm{~g}$ per $1000 \mathrm{ml}$ of water.

Blended syrup is prepared according to the recipes by adding the calculated amounts of components in the blending container with constant mixing in the following sequence: sugar syrup, juices, extracts, mulberry concentrate, flavoring bases, citric acid. The finished blended syrup is mixed until all components are evenly distributed in the volume.

Immediately after the preparation of the blended syrup, a "control drink" is prepared by mixing the blended syrup with the prepared water in a ratio with the specified recipe. "Control drink" is mixed and the content of the mass fraction of dry substances and titrated acidity are checked for compliance with the requirements of the recipe.

Then the blended syrup cooled to $8^{\circ} \mathrm{C}-10^{\circ} \mathrm{C}$ should be mixed with deaerated water cooled from $4{ }^{\circ} \mathrm{C}$ to $10{ }^{\circ} \mathrm{C}$ in the established ratio. The content of the mass fraction of dry substances of the prepared drink must correspond to the mass fraction of dry substances of the "Control drink". The acidity of the drink should be monitored. The acidity of the drink must match the recipe acidity of the drink.

Non-alcoholic functional drinks are poured into clear glass bottles, which are pre-rinsed with purified water with a volume of 0.5 liters approved for use with food products by the Russian Rospotrebnadzor.

Bottles with drinks are hermetically sealed with the use of closures approved by the Rospotrebnadzor of the Russian Federation.

Labels are pasted on each bottle. The glue used for gluing the label to the bottle should stick the label tightly, not damage the paper and label drawing, be easily washed off when washing bottles and not have an unpleasant smell.

Non-alcoholic functional beverages are stored at a temperature not lower than $0^{\circ} \mathrm{C}$ and not higher than $12^{\circ} \mathrm{C}$ and a relative humidity of not more than $75 \%$. Under the established 
storage conditions the shelf life of soft drinks prepared according to the recipe №1, №2, №3 is 7 days, №4, №5, №6, №7, №8, №9 is 11 days, №10, №11 is 14 days.

11 samples of beverages were prepared based on the selected components. Drinks made according to the technical conditions (TU) $918510-011-00493600-2015$ "Functional soft drinks. Mulberry with rosehip without sugar, Mulberry with grapes no sugar, Mulberry and dried apricots without sugar, Mulberry with feijoas and grapes, Mulberry with rosehip and grapes, Mulberry with sea buckthorn, and grapes, Mulberry and dried apricots and grapes, Mulberry with honey flavoring, and flavoring basis of "Oregano-Rosemary-Rose," Mulberry with grape flavoring, Mulberry with feijoas and grapes with stevia, Mulberry with sea buckthorn and grape with stevia".

The main component in the production of beverages was mulberry concentrate, which contains high antioxidant activity and mineral composition.

The use of fruits rich in anti-oxidants contributes to the deactivation of free radicals, carcinogens, and can even affect the processes that inhibit the development of tumors.

Initially, for the production of beverages, it was supposed to replace sugar syrup with concentrated mulberry syrup, in order to increase the nutritional value of the drink. Based on the selected components, 3 samples of the drink were prepared, consisting of mulberry concentrate, grape juice and extracts. Drink recipes are given in tables $2-10$.

Table 2. Recipe № 1 drink "Mulberry with rosehip without sugar».

\begin{tabular}{|l|c|c|c|c|}
\hline \multicolumn{1}{|c|}{ Ingredients } & \multirow{2}{*}{ Unit } & \multicolumn{2}{|c|}{ Dry matter content in raw materials } & \multirow{2}{*}{$\begin{array}{c}\text { Content of raw } \\
\text { materials in the } \\
\text { finished drink, \% }\end{array}$} \\
\cline { 3 - 5 } & & $\mathrm{kg}$ & $\%$ weights' & 95.86 \\
\hline Mulberry concentrate & $\mathrm{kg}$ & $\begin{array}{c}134.64 \\
(59.4 \mathrm{ml})\end{array}$ & 71.2 & 2.3595 \\
\hline Citric acid & $\mathrm{kg}$ & 2.6 & 90.75 & 2.4 \\
\hline Rosehip extract & $\mathrm{kg}$ & 40 & 6.0 & More than 0.4 \\
\hline $\mathrm{CO}_{2}$ & $\mathrm{~kg}$ & \multicolumn{3}{|c|}{ Up to 1000.0} \\
\hline Water & $\mathrm{dm}^{3}$ & \multicolumn{3}{|c|}{} \\
\hline
\end{tabular}

Table 3. Recipe № 1 drink "Mulberry with rosehip without sugar».

\begin{tabular}{|c|c|c|c|c|}
\hline \multirow[t]{2}{*}{ Ingredients } & \multirow[t]{2}{*}{ Unit } & \multicolumn{2}{|c|}{ Dry matter content in raw materials } & \multirow{2}{*}{$\begin{array}{l}\text { Content of raw materials in } \\
\text { the finished drink, } \%\end{array}$} \\
\hline & & $\mathrm{kg}$ & $\%$ weights' & \\
\hline $\begin{array}{l}\text { Mulberry } \\
\text { concentrate }\end{array}$ & $\mathrm{kg}$ & $\begin{array}{c}134.64 \\
(59.4 \mathrm{ml})\end{array}$ & 71.2 & 95.86 \\
\hline Citric acid & $\mathrm{kg}$ & 2.6 & 90.75 & 2.3595 \\
\hline $\begin{array}{c}\text { The juice of black } \\
\text { grapes }\end{array}$ & $\mathrm{kg}$ & 50 & 21.3 & 10.65 \\
\hline $\mathrm{CO} 2$ & $\mathrm{~kg}$ & \multicolumn{3}{|c|}{ More than 0.4} \\
\hline Water & $\mathrm{dm} 3$ & \multicolumn{3}{|c|}{ Up to 1000.0} \\
\hline
\end{tabular}

Table 4. Recipe № 3 drink "Mulberry with dried apricots without sugar».

\begin{tabular}{|c|c|c|c|c|}
\hline \multirow{2}{*}{ Ingredients } & \multirow{2}{*}{ Unit } & \multicolumn{2}{|c|}{ Dry matter content in raw materials } & $\begin{array}{c}\text { Content of raw materials } \\
\text { in the finished drink, \% }\end{array}$ \\
\cline { 3 - 5 } & & $\mathrm{kg}$ & \% weights & 95.86 \\
\hline Mulberry concentrate & $\mathrm{kg}$ & $\begin{array}{c}134.64 \\
(59.4 \mathrm{ml})\end{array}$ & 71.2 & 2.3595 \\
\hline Citric acid & $\mathrm{kg}$ & 2.6 & 90.75 & 4.71 \\
\hline Dried apricot extract & $\mathrm{kg}$ & 30 & 15.7 & More than 0.4 \\
\hline CO2 & $\mathrm{kg}$ & \multicolumn{3}{|c|}{ Up to 1000.0} \\
\hline Water & $\mathrm{dm} 3$ & \multicolumn{3}{|c|}{} \\
\hline
\end{tabular}

There are no non-natural food additives in the recipe of the obtained beverages. We used the natural pigments from plants as dyes. The resulting beverages were analyzed for organoleptic parameters. The drinks are opaque with a slight sediment, the color 
corresponds to the raw materials, but the taste in all three samples is the same, characteristic of the raw materials, sourish, not sweet enough.

To obtain functional drinks with organoleptic characteristics for different taste preferences, studies were carried out on the introduction of different amounts of mulberry concentrates, citric acid and the use of sugar syrup to make the drinks sweeter. Drink recipes are given in tables.

Table 5. Recipe № 4 "Mulberry drink with feijoa and grapes"

\begin{tabular}{|c|c|c|c|c|}
\hline \multirow{2}{*}{ Ingredients } & \multirow{2}{*}{ Unit } & Dry matter content in raw materials & $\begin{array}{c}\text { Content of raw materials } \\
\text { in the finished drink, \% }\end{array}$ \\
\cline { 3 - 4 } & & $\mathrm{kg}$ & $\%$ weights' & 24.208 \\
\hline Mulberry concentrate & $\mathrm{kg}$ & $34(15 \mathrm{ml})$ & 71.2 & 59.304 \\
\hline Sugar syrup & $\mathrm{kg}$ & 59.4 & 99.85 & 2.178 \\
\hline Citric acid & $\mathrm{kg}$ & 2.4 & 90.75 & 3.4 \\
\hline Feijoa extract & $\mathrm{kg}$ & 40 & 8.5 & 25.56 \\
\hline The juice of black grapes & $\mathrm{kg}$ & 120 & 21.3 & More than 0.4 \\
\hline $\mathrm{CO}_{2}$ & $\mathrm{~kg}$ & \multicolumn{3}{|c|}{ Up to 1000.0} \\
\hline Water & $\mathrm{dm}^{3}$ & \multicolumn{3}{|c|}{} \\
\hline
\end{tabular}

Table 6. Recipe № 5 drink "Mulberry with sea buckthorn and grapes"

\begin{tabular}{|c|c|c|c|c|}
\hline \multirow[t]{2}{*}{ Ingredients } & \multirow[t]{2}{*}{ Unit } & \multicolumn{2}{|c|}{ Dry matter content in raw materials } & \multirow{2}{*}{$\begin{array}{c}\text { Content of raw materials in the } \\
\text { finished drink, } \%\end{array}$} \\
\hline & & $\mathrm{kg}$ & $\%$ weights' & \\
\hline Mulberry concentrate & $\mathrm{kg}$ & $\begin{array}{c}45.4 \\
(20 \mathrm{ml})\end{array}$ & 71.2 & 32.3248 \\
\hline Sugar syrup & $\mathrm{kg}$ & 57.5 & 99.85 & 57.43 \\
\hline Citric acid & $\mathrm{kg}$ & 2.4 & 90.75 & 2.178 \\
\hline $\begin{array}{l}\text { The extract of sea } \\
\text { buckthorn }\end{array}$ & $\mathrm{kg}$ & 40 & 4.3 & 1.72 \\
\hline White grape juice & $\mathrm{kg}$ & 120 & 17.5 & 21 \\
\hline $\mathrm{CO} 2$ & $\mathrm{~kg}$ & \multicolumn{3}{|c|}{ More than 0.4} \\
\hline Water & $\mathrm{dm} 3$ & \multicolumn{3}{|c|}{ Up to 1000.0} \\
\hline
\end{tabular}

We also developed recipe № 6 drink "Mulberry with rosehip and grapes", Recipe № 7 drink "Mulberry with dried apricots and grapes", Recipe № 8 drink "Mulberry with honey flavor and flavor base "Oregano, Rosemary, Rosehip””, Recipe № 9 drink "Mulberry with grape flavor".

To develop dietary and diabetic beverages, sugar syrup was replaced with stevia syrup which is a natural sweetener.

It is known that the sweetness content of stevia leaves is 100-300 times higher than the sweetness of sucrose. Its sweet taste can be explained by valuable substances - diterpene glycosides. The sweet taste comes slowly, but lasts for a long time.

In the literature, there is evidence that stevia can prevent the development of cancer cells, eliminates caries and inflammatory processes in the oral cavity, improves digestion and strengthens the cardiovascular system, reduces blood sugar, and is an effective antiseptic. When using stevia in food, a person does not gain weight because it has almost no calories.

Stevia contains B vitamins, vitamins A, E, C, it is rich in minerals: zinc, phosphorus, rutin, selenium, chromium, copper, potassium, calcium, magnesium, as well as in antioxidants. Stevia is used in cooking, is resistant to high temperatures, as a vegetable matter, it is well soluble in liquid.

Drinks developed on the basis of this valuable natural sweetener are recommended for those who lose weight, want to put their skin, teeth and internal organs in good condition, fight parasites, as well as for people with diabetes.

The coefficient of sweetness of stevia that we used is 100 times higher than sugar, based on this, the calculation of the recipe is presented in the following tables. 
Table 7. Recipe № 10 drink "Mulberry with feijoa and grapes with stevia".

\begin{tabular}{|c|c|c|c|c|}
\hline Ingredients & Unit & \multicolumn{2}{|c|}{ Dry matter content in raw materials } & \multirow{2}{*}{$\begin{array}{c}\text { Content of raw } \\
\text { materials in the } \\
\text { finished drink, \% }\end{array}$} \\
\cline { 2 - 4 } & $\mathrm{kg}$ & $34(15 \mathrm{ml})$ & 71.2 & 24.208 \\
\hline $\begin{array}{c}\text { Mulberry } \\
\text { concentrate }\end{array}$ & $\mathrm{kg}$ & 0.594 & 99.85 & 59.304 \\
\hline Stevia & $\mathrm{kg}$ & 2.4 & 90.75 & 2.178 \\
\hline Citric acid & $\mathrm{kg}$ & 120 & 21.3 & 25.56 \\
\hline Feijoa extract & $\mathrm{kg}$ & $\mathrm{kg}$ & \multicolumn{3}{|c|}{ More than 0.4} \\
\hline $\begin{array}{c}\text { The juice of } \\
\text { black grapes }\end{array}$ & $\mathrm{dm}$ & \multicolumn{3}{|c|}{ Up to 1000.0} \\
\hline $\mathrm{CO}_{2}$ & & \multicolumn{3}{|c|}{} \\
\hline Water & $\mathrm{kg}$ & \multicolumn{3}{c}{} \\
\hline
\end{tabular}

Table 8. Recipe № 11 drink "Mulberry with sea buckthorn and grapes with stevia".

\begin{tabular}{|c|c|c|c|c|}
\hline \multirow[t]{2}{*}{ Ingredients } & \multirow[t]{2}{*}{ Unit } & \multicolumn{2}{|c|}{ Dry matter content in raw materials } & \multirow{2}{*}{$\begin{array}{l}\text { Content of raw materials } \\
\text { in the finished drink, } \%\end{array}$} \\
\hline & & $\mathrm{kg}$ & \% weights' & \\
\hline Mulberry concentrate & $\mathrm{kg}$ & $\begin{array}{c}45.4 \\
(20 \mathrm{ml})\end{array}$ & 71.2 & 32.3248 \\
\hline Stevia & $\mathrm{kg}$ & 0.575 & 99.85 & 57.43 \\
\hline Citric acid & $\mathrm{kg}$ & 2.4 & 90.75 & 2.178 \\
\hline The extract of sea buckthorn & $\mathrm{kg}$ & 40 & 4.3 & 1.72 \\
\hline White grape juice & $\mathrm{kg}$ & 120 & 17.5 & 21 \\
\hline $\mathrm{CO}_{2}$ & $\mathrm{~kg}$ & \multicolumn{3}{|c|}{ More than 0.4} \\
\hline Water & $\mathrm{dm}^{3}$ & \multicolumn{3}{|c|}{ Up to 1000.0} \\
\hline
\end{tabular}

We used a 25-point system for the tasting assessment of the prepared beverages/

When providing a tasting assessment of the prepared samples of beverages, the following was evaluated:

- Appearance,transparency, color, the maximum score when evaluating these indicators is 7 points.

- Taste and aroma, the maximum rating score is 12 points.

- Carbon dioxide saturation, the maximum score is 6 points.

If the highest score is $23-25$ points, the quality of the drink is excellent, 19-22 pointsgood, $15-18$ points- satisfactory, less than 15 points - unsatisfactory.

According to the tasting, all prepared samples of soft drinks have a non-transparent liquid, a pleasant taste and aroma, the presence of sediment due to the characteristics of the raw materials used.

The drinks were saturated with carbon dioxide to give them tonic and foamy properties. This indicator is most pronounced in the drinks "Mulberry with grapes, Mulberry with feijoa and grapes".

The highest score was given to drinks prepared according to recipes № 2 "Mulberry with grapes", №4 "Mulberry with feijoa and grapes", №5 "Mulberry with sea buckthorn and grapes", №9 "Mulberry with grape flavor". It was also noted that all drinks deserve high praise and can be recommended for the production of soft drinks.

\section{Conclusion}

As a result of the research, we calculated, selected and developed recipes for functional drinks based on mulberry concentrate with the addition of fruit and berry components for the general category of citizens, for dietary nutrition and for diabetic nutrition. 
Drinks are differentiated according to the developed production technology into the following series:

1. Drinks without sugar and without sugar substitutes:

- "Mulberry with rosehip without sugar»,

- "Mulberry with grapes without sugar»

- "Mulberry with dried apricots without sugar»

2. Drinks based on mulberry and fruit and berry components with a low content of sugar syrup:

- "Mulberry with feijoa and grapes"

- "Mulberry with rosehip and grapes"

- "Mulberry with sea buckthorn and grapes"

- "Mulberry with rosehip and grapes"

3. Mulberry beverages with flavorings:

- "Mulberry with honey flavor and flavoring base "Oregano-Rosemary-Rosehip"",

- "Mulberry with grape flavor"

4. Drinks of mulberry and fruit and berry components with stevia:

- "Mulberry with feijoa and grapes with stevia"

- "Mulberry with sea buckthorn and grapes with stevia"

The prepared functional drinks meet the requirements of GOST in terms of organoleptic and physicochemical indicators.

The developed drinks based on mulberry and fruit and berry raw materials according to GOST R 56543 are functional, since they contain functional food ingredients, such as vitamin $\mathrm{C}, \mathrm{A}, \mathrm{E}, \beta$-carotene, $\mathrm{K}$ macro elements $\mathrm{Na}, \mathrm{K}, \mathrm{Ca}, \mathrm{Mg}$ and trace elements $\mathrm{Fe}, \mathrm{Zn}$ in the amount of more than $15 \%$ of the daily intake.

The tasting evaluation of the prepared drinks showed that all drinks are of excellent and good quality.

In terms of microbiological and hygienic requirements, non-alcoholic beverages comply with TR CU 021/2011 "On food safety"

The optimal shelf life of drinks based on natural raw materials has been determined.

The production of all functional drinks is cost effective. The profit ranges from RUB $27,912.8$ to RUB 34,606 per 1,000 liters of drink, with a profitability level of 66.3 to $136.3 \%$. The greatest economic effect is obtained in the production of functional drinks with stevia and sugar.

\section{References}

1. M.D. Mukailov, N.A. Ulchibekova, T.A. Isrigova, M.E. Akhmedov, U.A. Selimova, Functional foods produced from strawberries. - 2020 International J. of Advanced Science and Technology.

2. T.A. Isrigova, M.M. Salmanov, M.D. Mukailov, T.N. Ashurbekova, U.A. Selimova, Research J. of Pharmaceutical, Biological and Chemical Sciences.

3. T.A. Isrigova, M.M. Salmanov, Method for preserving fruits and berries, Patent for invention RU 2347505 C1.- 27.02.2009.- Application No. 2007130948/13 dated 13.08.2007.

4. L.A. Daudova, T.A. Isrigova, T.N. Daudova, Modernization of the agro-industrial complex. Collection of materials, All-Russian scientific-practical conference dedicated to the 80th anniversary of the Faculty of Agrotechnology and Land Management "Dagestan State Agrarian University named after MM Dzhambulatov", 180 (2013).

5. S.A. Bekuzarova, E.Yu. Volokh, E.S. Dzodzieva, T.A. Isrigova, Problems of the development of the agro-industrial complex of the region, T. 27, 3(27), 124 (2016). 
6. T.A. Isrigova, M.M. Salmanov, U.A. Selimova, L.B. Bagavdinova, Improving the quality and safety of food products, 129 (2014)

7. I.V. Musaeva, M.D. Mukailov, T.A. Isrigova., A.B. Aliev, B.I. Shikhshabekova, A.D. Guseinov, A.S. Abdusamadov, E.M. Alieva, Problems of the development of the agroindustrial complex of the region, 2(38), 237 (2019).

8. T.A. Isrigova, M.M. Salmanov, Modern problems of mechanization of agricultural production, 84 (2004).

9. A.S. Khamitsaeva, A.R. Budaev, A.A. Dziova, R.T. Dzagoeva, S.F. Zokoev, I.O. Malieva, T.A. Isrigova, Method for the production of minced meat semi-finished products, Patent for invention RU 2631386 C1, 21.09.2017.-Application No. 2016117619 dated 04.05.2016.

10. A. Batukaev, M. Mukailov, M. Batukayev, T. Minkina, S. Sushkova, Use of growth regulators in grapes grinding by in vitro method

11. A. Batukaev, M. Mukailov, A. Ezaov, T. Minkina, S. Sushkova, Effect of mineral fertilizers on the productivity of intensive apple plantations in the south of russia

12. L.B. Huseynova, Development of technology elements for the production of functional drinks based on purified water: dis.... Cand. S-x. Sciences: 05.18.01: protected 17.04.2018, author L.B. Guseinva -Makhachkala, 157 (2018).

13. M.D. Mukailov, N.A. Ulchibekova, Food technology. Izv. universities, 1, 57 (2013)

14. M.V. Palagina, Izvestiya vuzov. Food technology, 4, 42 (2009).

15. M.V. Palagina, Ya. V. Dubnyak, Yu.V. Prikhodko, Beer and drinks, 4, 44 (2009).

16. T.L. Pilat, O.A. Belykh, L.Yu. Volkova, Food industry, 2, 71 (2013).

17. T.L. Pilate, A.A. Ivanov, Biologically active food additives (theory, production, application) (Avvalon, 2002).

18. A.D. Poverin, Beer and drinks, 4, 34 (2006).

19. M.D. Mukailov, M.B. Khokonova, Problems of development of the agro-industrial complex of the region, 2(30), 94 (2017). 